\title{
Mixed Cropping System on Diversity and Density of Plant Parasitic Nematodes
}

\author{
Kingsley Osei ${ }^{1}$, Haruna Braimah ${ }^{1}$, Umar Sanda Issa $^{1} \&$ Yaw Danso ${ }^{1}$ \\ ${ }^{1}$ Crops Research Institute, Kumasi, Ghana \\ Correspondence: Kingsley Osei, Crops Research Institute, P.O. Box 3785, Kumasi, Ghana. E-mail: \\ oseikingsley4@gmail.com
}

Received: July 26, 2016

Accepted: September 17, $2016 \quad$ Online Published: October 15, 2016

doi:10.5539/jas.v8n11p147

URL: http://dx.doi.org/10.5539/jas.v8n11p147

\begin{abstract}
The potential of mixed cropping system on the diversity and suppression of nematodes was investigated at two locations in Ghana. The treatments in the study were; sole plantain, sole cassava and plantain+cassava systems replicated five and four times in a randomized complete block design (RCBD) at Kwadaso in the Ashanti and Assin Foso in the Central region of Ghana respectively. Growth parameters (height and girth) and components of yield (No. of suckers/plant, bunch weight/plant, No. of hands/plant, No. of fingers/plant) were studied on plantain in addition to No. of weevils per plant. On cassava, total biomass, tuber number and tuber weight (yield) were analyzed using GenStat software and means were separated with Fisher's least significance test at $\alpha=0.05$. There were no differences in height and girth of plantain at Assin Foso. However, plant height was $25 \%$ and girth $13 \%$ more under sole plantain system over the mixed cropping system at Kwadaso. The sole plantain system recorded $60 \%$ and $75 \%$ more suckers than the Plantain-Cassava system at both locations. Mixed and sole cropping systems did not influence the diversity of nematode community but significant differences were observed in the density of the nematode taxa encountered under the two systems. Throughout the investigation at both locations, it was observed that the mixed cropping system recorded significantly $(\mathrm{P}<0.05)$ lower nematode population densities in comparison to sole cropping system. It is therefore true that an agro-ecological strategy for pests and diseases control is the growing of a mixture of crops differing in their susceptibility to pests and pathogens
\end{abstract}

Keywords: mixed cropping system, monoculture system, nematode species

\section{Introduction}

Genetic uniformity of monocultures has been reported to predispose crops to pests and diseases outbreaks (Meung et al., 2003). Since the introduction of plant diversity increases the number of individual functional traits and potential ecosystem services (Hajjar et al., 2008; Malezieux et al., 2009) an agro-ecological strategy for pests and diseases control is the growing of a mixture of crops differing in their susceptibility to pests and pathogens (Smithson \& Lenne, 1996; Wolfe, 1985). Mixed culture is recommended for reduction of risk of total crop failure, production of a variety of produce, and improvement of soil fertility where legumes are included which ultimately improve yield of associated crops.

Plant parasitic nematodes (PPN) are among the most important pests of crops worldwide (Yadav \& Sehgal, 2010). Mono and mixed cropping systems are affected by PPN parasitism however; the type of mixed cropping system adopted might influence the diversity and density of PPN community. In Ghana, crops may be grown together in mixed cultures often following a system that has been long established and generally successful. It has been observed that crop losses due to pests and diseases are on the ascendency as improved crop cultivars are cultivated in monoculture systems. The greatest incentive to the Ghanaian farmer in practicing mixed culture therefore is food security.

Plantain (Musa spp.) is an important food source for many people in the tropics and sub-tropics of the world (Kainga \& Seiyabo, 2012). In Ghana, plantain is a starchy staple crop of considerable importance, which contributes about 13\% of the Agricultural Gross Domestic Product (GNA, 2007). About $90 \%$ of production is consumed locally because plantain is ranked high in food preference (Schill et al., 1996). Consequently it serves as an important source of family income as a result of its high price compared with other starchy staples (Dadzie \& Wainwright, 1995). In addition, its production provides job opportunities (Robinson, 2000). 
Cassava, Manihot esculenta on the other hand, is the most important vegetatively propagated food crop and the second most important food staple in terms of calories per capita in Africa (Nweke et al., 2002). The major nutritional component of cassava is carbohydrate. In Ghana, cassava accounts for a daily calorie intake of $30 \%$ and is grown by almost every farming family (FAO, 2006). The importance of cassava to many Africans is epitomized in Ewe (a language spoken in Ghana, Togo and Benin) for the plant, agble, meaning "there is life" (Manu-Aduening, 2005). The crop plays an important role in Ghana's economy; it contributes $22 \%$ of the Agriculture Gross Domestic Product (Al-hassan, 1989).

Nematode species which are detrimental to plantain are those which destroy the primary roots, disrupting the anchorage system and resulting in toppling of the plants. Radopholus similis, Pratylenchus species and Helicotylenchus multicintus are the most widespread and important (Gowen et al., 2005). Plant-parasitic nematodes most frequently found associated with cassava are Meloidogyne spp., Pratylenchus brachyurus, Rotylenchulus reniformis and Helicotylenchus dihysteria (Coyne et al., 2003). These nematode species appear however, of limited importance, with little evidence of significant effect on the crop. However, the significance of nematodes in the cultivation of cassava cannot be overemphasized as some nematodes may interact with other pathogenic organisms in the development of disease complexes (Bridge et al., 2005).

The banana weevil, Cosmopolites sordidus is another major pest of plantain. The weevil can confuse the diagnosis of a nematode problem because symptoms of damage are similar (Gowen et al., 2005). With fungi (Cylindrocarpon spp., Fusarium spp., Rhizoctonia spp. and Cylindrocladium spp.) the problem becomes even more complex as nematodes and fungi occur within the same cells and infestations result in the same types of discoloration and necrosis (Jones, 2000; Riséde \& Simoneau, 2004). In preliminary studies on cassava in Nigeria, the presence of $M$. incognita substantially increased the incidence and severity of damage to storage roots by Botrydiplodia theobromae a causal agent of root rot (Dixon et al., 2003).

We must understand and manage these complex organisms so that we may continue to develop and sustain our food production systems (Barker et al., 1994). The potential of farming systems to manage nematode populations below the economic threshold level (ETL) must be investigated. Such a strategy might reduce the over reliance on synthetic chemicals which are detrimental to man and the environment. Therefore, the objective of this study was to evaluate the effect of plantain-cassava mixed culture on the diversity and density of plant-parasitic nematodes in southern Ghana.

\section{Materials and methods}

\subsection{Treatments and Experimental Procedure}

Three treatments; sole plantain, sole cassava and mixed plantain-cassava were replicated five and four times in a randomized complete block design (RCBD) at Kwadaso in the Ashanti and Assin Foso in the Central region of Ghana respectively. Both locations are in the forest belt and experience a bi-modal rainfall pattern. The variety of cassava used was "Doku" while the plantain was a local variety. Completely decomposed poultry manure was used to fertilize plantain (in both the sole and mixed culture plots) at a rate of $900 \mathrm{~g} / \mathrm{plant}$ at planting time. A plot measured $12 \times 12 \mathrm{~m}$. At Kwadaso, plantain was planted on June 15, 2010 and cassava on June 23, 2010. Both cassava and plantain were planted at Assin Fosu on July 15, 2010. Plantain was planted at a spacing of $3 \times 3 \mathrm{~m}$ while cassava was at $1 \times 1 \mathrm{~m}$ at both locations.

\subsection{Soil and Root Sampling for Nematode Assay}

Soil samples were collected at two time periods; at the start of the trial before the planting of plantain and cassava and during 14 months after planting when cassava was harvested and about $70 \%$ of the first plantain crop had been harvested. Soil samples were randomly collected with a $5 \mathrm{~cm}$ soil auger to a depth of $20 \mathrm{~cm}$. Roots of plantain were also sampled at the time of soil sampling. The soil samples, $200 \mathrm{~cm}^{3}$ per treatment and $5 \mathrm{~g}$ of root samples were extracted using the modified Baermann funnel method. After $24 \mathrm{~h}$ of extraction, samples were fixed with TAF (Formalin-37\% formaldehyde $7.6 \mathrm{ml}$, Tri-ethylamine $2 \mathrm{ml}$ and distilled water $90.4 \mathrm{ml}$ ) and second, third and fourth stage nematodes were mounted on aluminium double-coverglass slides and specimens were identified (CIH, 1978) under a stereo microscope at magnification 100x using morphological characteristics such as the spear (stylet), head skeleton, lumen of the oesophagus, excretory pore and spicules.

\subsection{Data Analysis}

Statistical analysis was performed using Genstat 8.1 software. Yield, being continuous data was not transformed but nematode count data was $\log (\ln (\mathrm{x}+1))$ transformed to improve homogeneity of variance before analysis. Significant mean separation was determined with Fisher's least significance test at $\alpha=0.05$. 


\section{Results and Discussion}

Growth parameters (height and girth) and components of yield (No. of suckers/plant, bunch weight/plant, No. of hands/plant, No. of fingers/plant) were studied on plantain in addition to No. of weevils per plant. The different farming systems; Sole plantain (mono-cropping) and Plantain + Cassava (mixed cropping) did not show differences in plant growth parameters (height and girth) of plantain at Assin Foso. However, differences were recorded at Kwadaso. Plant height was $25 \%$ and girth $13 \%$ more under sole plantain system over the mixed cropping system at Kwadaso.

Table 1a. Plantain growth parameters, components of yield and weevil infestation at Assin Foso

\begin{tabular}{llllllll}
\hline Farming system & Height $(\mathrm{m})$ & Girth $(\mathrm{cm})$ & No. suckers & Bunch weight $(\mathrm{kg})$ & No. hands & No. fingers & No. weevils \\
\hline Sole Plantain & 2.05 & 43.60 & 5.00 & 21,792 & 21,371 & 95,433 & $696(2.8)$ \\
Plantain +Cassava & 2.02 & 37.80 & 2.00 & 19,592 & 20,942 & 82,225 & $346(2.5)$ \\
Mean & $\mathbf{2 . 0 3 5}$ & $\mathbf{4 0 . 7}$ & $\mathbf{3 . 5}$ & $\mathbf{2 0 , 6 9 2}$ & $\mathbf{2 1 , 1 5 6 . 5}$ & $\mathbf{8 8 , 8 2 9}$ & $\mathbf{5 2 1}(\mathbf{2 . 6 5})$ \\
Lsd (5\%) & 0.97 & 7.03 & 1.93 & $8,292.8$ & $6,386.7$ & 28,844 & $245(0.2)$ \\
\hline
\end{tabular}

Table 1b. Plantain growth parameters, components of yield and weevil infestation at Kwadaso

\begin{tabular}{llllllll}
\hline Farming System & Height $(\mathrm{m})$ & Girth $(\mathrm{cm})$ & No. suckers & Bunch weight $(\mathrm{kg})$ & No. hands & No. fingers & No. weevils \\
\hline Sole plantain & 2.47 & 42.37 & 4.00 & 32,173 & 24,417 & 98,611 & $312(1.9)$ \\
Plantain +Cassava & 1.85 & 35.99 & 1.00 & 26,567 & 23,067 & 82,629 & $227(1.6)$ \\
Mean & $\mathbf{2 . 1 6}$ & $\mathbf{3 9 . 1 8}$ & $\mathbf{2 . 5}$ & $\mathbf{2 9 , 3 7 0}$ & $\mathbf{2 3 , 7 4 2}$ & $\mathbf{9 0 , 6 2 0}$ & $\mathbf{2 6 9 . 5 ( 1 . 7 5 )}$ \\
Lsd (5\%) & 0.14 & 3.29 & 1.34 & $7,953.9$ & $3,265.6$ & $3,865.7$ & $94(1.1)$ \\
\hline
\end{tabular}

Similarly, no differences were recorded in bunch weight (yield) at both locations. However, significant differences were observed regarding the No. of suckers/plant and No. of weevils/plant at both locations. The Sole plantain system recorded $60 \%$ and $75 \%$ more suckers than the Plantain-Cassava system at both locations (Tables $1 \mathrm{a}$ and $1 \mathrm{~b}$ ). The mixed cropping system negatively affected sucker production.

The significantly low weevil population recorded under the Plantain-Cassava system was $101 \%$ less than the population recorded under the Sole plantain system at Assin Foso (Table 1a). Similarly, the Plantain-Cassava system recorded 34\% less weevils than in the Sole plantain system at Kwadaso (Table 1b). The results of the current study corroborate the finding that "the growing of a mixture of crops is an agro-ecological way of controlling pests and diseases" (Smithson \& Lenne, 1996).

Three parameters; total biomass, tuber number and tuber weight (yield) were studied on cassava under the two farming systems (Sole cropping and mixed cropping). Differences observed were not significant in any of the parameters studied (Figures 1a and 1b).

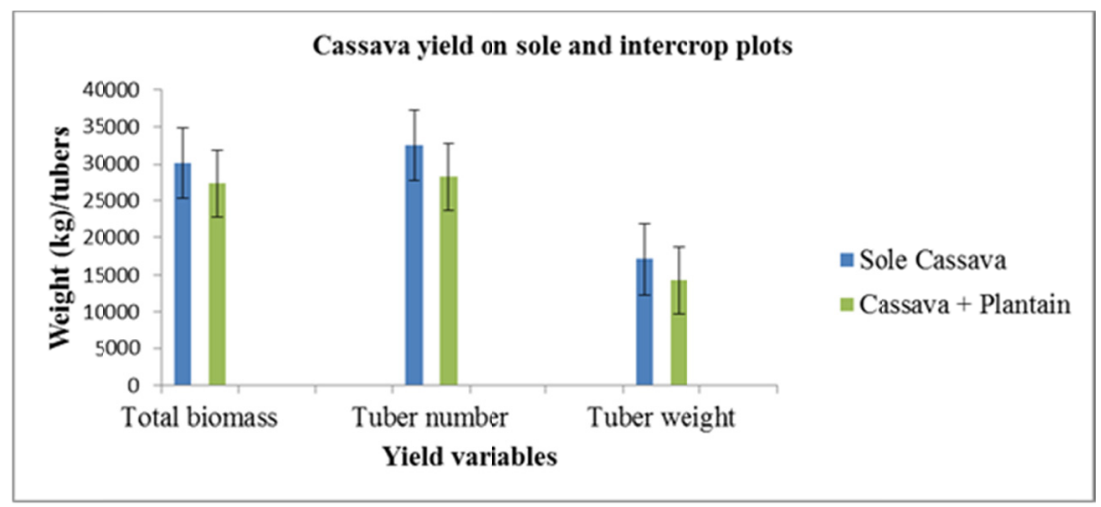

Figure 1a. Cassava yield in sole and intercrop systems at Assin Foso 


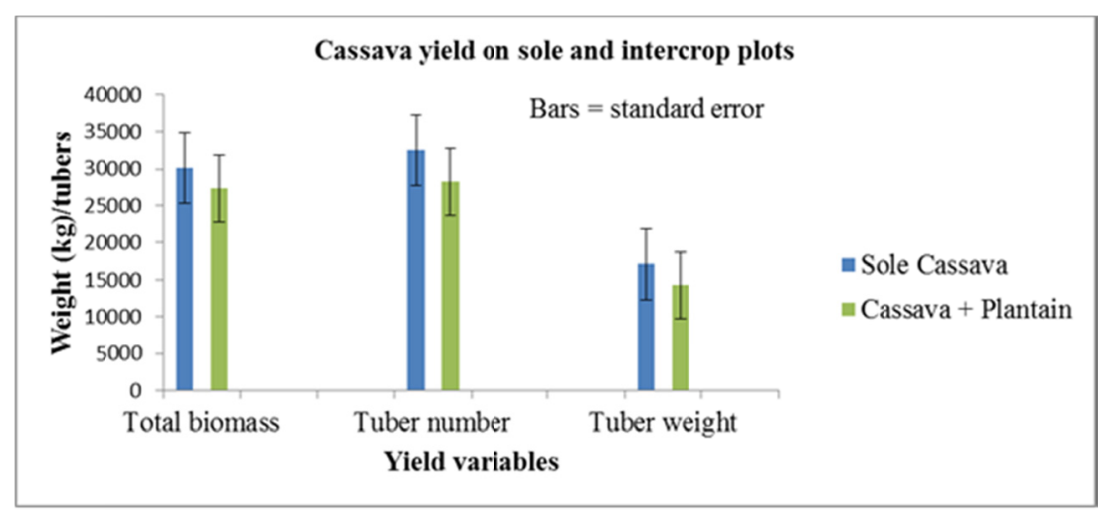

Figure 1b. Cassava yield in sole and intercrop systems at Kwadaso

Four plant parasitic nematodes belonging to the Order: Tylenchida were encountered at both locations at the beginning and at the end of experiment. The nematodes encountered were: Meloidogyne spp., Pratylenchus coffeae, Rotylenchulus reniformis and Helicotylenchus multicintus. From the initial soil samples, nematode population $/ 200 \mathrm{~cm}^{3}$ soil was comparatively higher at Assin Fosu with $R$. reniformis being the most abundant while H. multicintus predominated at Kwadaso (Figure 2).

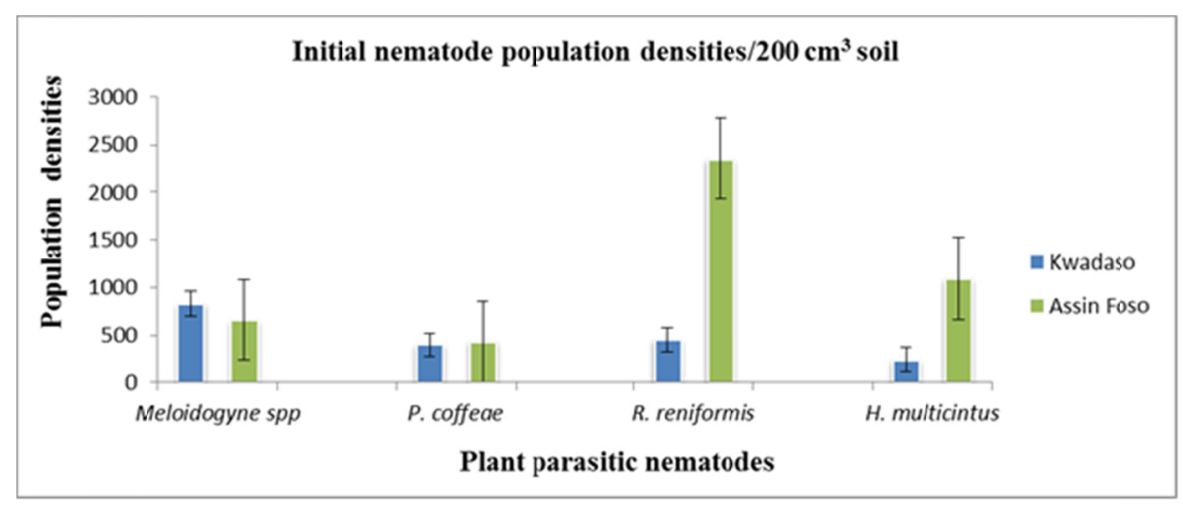

Figure 2. Initial nematode population densities $/ 200 \mathrm{~cm}^{3}$ soil

Throughout the investigation at both locations, it was observed that the mixed cropping system recorded significantly $(\mathrm{P}<0.05)$ lower population densities regarding; Meloidogyne spp., $P$. coffeae and $R$. reniformis in comparison to sole cropping treatment. However, there were no differences in population of $H$. multicintus in both treatments at both locations. The sole cropping system recorded (82 and 637) \% more Meloidogyne spp. and $R$. reniformis than the mixed cropping system at Assin Foso while (351 and 280) \% more Meloidogyne spp. and $R$. reniformis were recorded at Kwadaso respectively (Tables $2 \mathrm{a}$ and $2 \mathrm{~b}$ ).

Table 2a. Plant parasitic nematodes $/ 200 \mathrm{~cm}^{3}$ in soil samples at harvest at Assin Foso

\begin{tabular}{lllll}
\hline Farming system & H. multicintus & Meloidogyne spp. & P. coffeae & R. reniformis \\
\hline Sole plantain & $9.5(0.58)^{1} \mathrm{~b}$ & $51.0(1.56) \mathrm{c}$ & $42.0(1.55) \mathrm{c}$ & $33.2(1.47) \mathrm{b}$ \\
Plantain + Cassava & $9.2(0.42) \mathrm{b}$ & $28.0(1.42) \mathrm{b}$ & $14.2(0.31) \mathrm{b}$ & $4.5(0.29) \mathrm{a}$ \\
Sole cassava & $1.0(0.00) \mathrm{a}$ & $8.8(0.91) \mathrm{a}$ & $4.0(0.42) \mathrm{a}$ & $9.0(0.56) \mathrm{a}$ \\
Mean & $\mathbf{6 . 6 ( 0 . 3 3 )}$ & $\mathbf{2 9 . 3 ( 1 . 2 9 )}$ & $\mathbf{2 0 . 0 7 ( 0 . 7 6 )}$ & $\mathbf{1 5 . 5 7 ( \mathbf { 0 . 7 7 } )}$ \\
Lsd (5\%) & $0.37(0.29)$ & $0.18(0.01)$ & $0.10(0.07)$ & $0.03(0.06)$ \\
\hline
\end{tabular}

Note. Values are means of 4 replications. Means followed by the same letters do not differ significantly. ${ }^{1} \log$ transformed $[\ln (x+1)]$ data used in analysis in parenthesis. 
Table 2b. Plant parasitic nematodes $/ 200 \mathrm{~cm}^{3}$ in soil samples at harvest at Kwadaso

\begin{tabular}{lllll}
\hline Farming system & H. multicintus & Meloidogyne spp. & P. coffeae & R. reniformis \\
\hline Sole plantain & $71.4(1.81)^{1} \mathrm{~b}$ & $307.0(2.42) \mathrm{b}$ & $261.0(2.12) \mathrm{b}$ & $293.0(2.37) \mathrm{b}$ \\
Plantain + Cassava & $29.8(1.45) \mathrm{b}$ & $68.0(1.59) \mathrm{a}$ & $12.0(0.88) \mathrm{a}$ & $77.0(1.85) \mathrm{ab}$ \\
Sole Cassava & $1.0(0.00) \mathrm{a}$ & $55.0(1.65) \mathrm{a}$ & $7.0(0.62) \mathrm{a}$ & $28.0(1.11) \mathrm{a}$ \\
Mean & $\mathbf{3 4 . 1}(\mathbf{1 . 0 9})$ & $\mathbf{1 4 3 . 3}(\mathbf{1 . 8 9})$ & $\mathbf{9 3 . 3}(\mathbf{1 . 2 1})$ & $\mathbf{1 3 2 . 7}(\mathbf{1 . 7 8 )}$ \\
Lsd (5\%) & $0.002(0.001)$ & $0.012(0.014)$ & $0.052(0.002)$ & $0.032(0.015)$ \\
\hline
\end{tabular}

Note. Values are means of 5 replications. Means followed by the same letters do not differ significantly. ${ }^{1} \log$ transformed $[\ln (\mathrm{x}+1)]$ data used in analysis in parenthesis.

The sole cassava system recorded significantly least population densities in all the four nematodes encountered at both locations which did not result in any differences in the parameters studied on cassava (Tables $2 \mathrm{a}$ and $2 \mathrm{~b}$ ). All the four nematode species have been reported to be associated with plantain and cassava cultivation (Coyne et al., 2003; Gowen et al., 2005). The insignificantly low nematode numbers recovered from the rhizosphere of cassava has confirmed the fact that nematodes are of limited importance, with little evidence of significant effect on the crop (Bridge et al., 2005).

Table 3a. Plant parasitic nematode population densities $/ 5 \mathrm{~g}$ plantain root at Assin Foso

\begin{tabular}{lllll}
\hline Treatment & H. multicintus & Meloidogyne spp. & P. coffeae & R. reniformis \\
\hline Sole plantain & $210(1.26)^{1} \mathrm{~b}$ & $166(2.15) \mathrm{b}$ & $104(1.98) \mathrm{b}$ & $24(1.18) \mathrm{b}$ \\
Plantain+ cassava & $4.2(0.57) \mathrm{a}$ & $24(1.18) \mathrm{a}$ & $18(1.10) \mathrm{a}$ & $4.0(0.56) \mathrm{a}$ \\
Mean & $\mathbf{1 2 6}(\mathbf{0 . 9 2})$ & $\mathbf{9 5}(\mathbf{1 . 6 7})$ & $\mathbf{6 1}(\mathbf{1 . 5 4})$ & $\mathbf{1 4}(\mathbf{0 . 8 7})$ \\
Lsd $(5 \%)$ & $0.088(0.071)$ & $0.096(0.115)$ & $0.050(0.034)$ & $0.074(0.02)$ \\
\hline
\end{tabular}

Note. Values are means of 4 replications. Means followed by the same letters are not significantly different. ${ }^{1} \log$ transformed $[\ln (\mathrm{x}+1)]$ data used in analysis in parenthesis.

Table 3b. Plant parasitic nematode population densities/5 g plantain root at Kwadaso

\begin{tabular}{lllll}
\hline Treatment & H. multicintus & Meloidogyne spp. & P. coffeae & R. reniformis \\
\hline Sole plantain & $148(2.05)^{1 \mathrm{~b}}$ & $147(2.10) \mathrm{b}$ & $297(2.19) \mathrm{b}$ & $66(1.59) \mathrm{b}$ \\
Plantain+ cassava & $22(0.79) \mathrm{a}$ & $34(1.14) \mathrm{a}$ & $76(1.25) \mathrm{a}$ & $8(0.64) \mathrm{a}$ \\
Mean & $\mathbf{8 5 ( 1 . 4 2 )}$ & $\mathbf{9 0}(\mathbf{1 . 6 2})$ & $\mathbf{1 8 6 . 5 ( 1 . 7 2 )}$ & $\mathbf{3 7}(\mathbf{1 . 1 2})$ \\
Lsd $(5 \%)$ & $0.040(0.017)$ & $0.027(0.033)$ & $0.216(0.019)$ & $0.047(0.005)$ \\
\hline
\end{tabular}

Note. Values are means of 5 replications. Means followed by the same letters do not differ significantly. ${ }^{1} \log$ transformed $[\ln (\mathrm{x}+1)]$ data used in analysis in parenthesis.

Nematode population densities recovered from plantain roots under the sole cropping system were significantly $(\mathrm{P}<0.05)$ higher than under the mixed cropping system. For instance, Meloidogyne spp. and Pratylenchus coffeae populations under the sole plantain system were (592 and 332\%) and (478 and 291\%) higher than under the mixed cropping system at Assin Foso and Kwadaso respectively (Tables 3a and 3b). Severe infestation of plantain root system by plant parasitic nematodes often result in toppling over of plants particularly at fruiting stage (Gowen et al., 2005) leading to significant yield losses.

\section{Acknowledgements}

Authors are grateful to the West Africa Agricultural Productivity Programme (WAAPP) for funding the study.

\section{References}

Al-Hassan, R. M. (1989). Cassava in the economy of Ghana. In: Status of data on cassava in major producing countries of Africa. COSCA working paper No. 3. Collaborative study on Cassava in Africa, IITA, Ibadan, Nigeria. 
Barker, K. R., Hussey, R. S., \& Krusberg, L. R. (1994). Plant and soil nematodes: societal impact and focus for the future. J. Nematol., 26, 127-137.

Bridge, J., Coyne, D. L., \& Kwoseh, C. K. (2005). Nematode parasites of tropical root and tuber crops. In M. Luc, R. A. Sikora, \& J. Bridge (Eds.), Plant Parasitic Nematodes in Subtropical and Tropical Agriculture (2nd ed., pp. 221-258). CAB International Publishing, Wallingford, UK. http://dx.doi.org/10.1079/ 9780851997278.0221

CIH. (1978). Commonwealth Institute of Helminthology Description of plant parasitic nematodes. CAB International, Wallingford, UK.

Coyne, D. L., Talwana, H. A. L., \& Maslen, N. R. (2003). Plant-parasitic nematodes associated with root and tuber crops in Uganda. Afr. Plt. Protect., 9, 87-98.

Dadzie, B. K., \& Wainwright, H. (1995). Plantain utilization in Ghana. Trop Sci., 35, 405-410.

Dixon, A. G. O., Bandyopadhyay, R., Coyne, D., Ferguson, M., Ferris, R. S. B., Hanna, R.,...Ortiz, R. (2003). Cassava: From poor farmer's crop to pacesetter of Africa rural development. Chronica Hortica, 43, 8-15.

FAO. (2006). Food Outlook. No. 1 June Outlook.

GNA. (2007). Ghana News Agency Report 2007. Plantain production in Ghana increases

Gowen, S. R., Quénéhervé, P., \& Fogain, R. (2005). Nematode parasites of bananas and plantains. In M. Luc, R. A. Sikora, \& J. Bridge (Eds.), Plant Parasitic Nematodes in Subtropical and Tropical Agriculture (2nd ed., pp. 611-643). CAB International Publishing, Wallingford, UK. http://dx.doi.org/10.1079/9780851997 278.0611

Hajjar, R., Jarvis, D. I., \& Gemmill-Herren, B. (2008). The utility of crop genetic diversity in maintaining ecosystem services. Agric. Ecosystems \& Ent., 123, 261-270. http://dx.doi.org/10.1016/j.agee.2007.08.003

Jones, D. R. (2000). Diseases of Banana, Abaca and Enset. CAB International, Wallingford, UK.

Kainga, P. E., \& Seiyabo, I. T. (2012). Economics of plantain production in Yenagoa local government area of Bayelsa State. J. Agric. and Soc Research, 12(1), 114-123.

Malezieux, E., Crozat, Y., Dupraz, C., Laurans, M., Makwoski, D., Ozier-Lafontaine, H., ... Valantin-Morrison, M. (2009). Mixing plant species in cropping systems: Concepts, tools and models. A review. Agron. for Sustainable Devt., 29, 43-62. http://dx.doi.org/10.1051/agro:2007057

Manu-Aduening, J. (2005). Participatory Breeding for superior mosaic-resistant cassava in Ghana (pp. 33-38, $\mathrm{PhD}$. Thesis). University of Greenwich, UK.

Meung, H., Zhu, Y. Y., Revilla-Molina, I., Fan, J. X., Chen, H. R., Pangga, I., ... Mew, T. W. (2003). Using genetic diversity to achieve sustainable rice disease management. Plt. Disease, 87, 1156-1169. http://dx.doi.org/10.1094/PDIS.2003.87.10.1156

Nweke, F. I., Spencer, D. S. C., \& Lynam, J. K. (2002). The cassava transformation, Africa's best-kept secret. East Lansing, MI, USA: Michigan University Press.

Riséde, J. M., \& Simoneau, P. (2004). Pathogenic and genetic diversity of soil borne isolates of Cylindrocladium from banana cropping systems. Eur. J. Plt. Pathol., 110, 139-154. http://dx.doi.org/10.1023/B:EJPP.00000 $15337.54178 . \mathrm{c} 0$

Robinson, J. C. (2000). Banana productivity: The impact of agronomic practices. Proceedings of the International Symposium on Banana and Plantain for Africa, Acta Hort., 540 ISHS 2000 (pp. 247-258).

Schill, P., Gold, C. S., \& Afreh-Nuamah, K. (1996). Assessment and characterization of constraints in plantain production in Ghana as an example for West Africa. Plantain and banana production and research in West and Central Africa. Proceedings of a regional workshop, held at Onne, River State, Nigeria, IITA, Ibadan, Nigeria (pp. 45-51).

Smithson, J. B., \& Lenne, J. M. (1996). Varietal mixtures: A viable strategy for sustainable productivity in subsistence agriculture. Ann. Applied Biol., 128, 127-158. http://dx.doi.org/10.1111/j.1744-7348.1996. tb07096.x

Wolfe, M. S. (1985). The current status and prospects of multiline cultivars and variety mixtures for disease resistance. Ann. Rev. Phytopathol., 23, 251-273. http://dx.doi.org/10.1146/annurev.py.23.090185.001343 
Yadev, S. M., \& Sehgal, M. (2010). Management of plant parasitic nematodes through chickpea-groundnut cropping system. Pakis. J. Nema., 28(2), 361-362.

\section{Copyrights}

Copyright for this article is retained by the author(s), with first publication rights granted to the journal.

This is an open-access article distributed under the terms and conditions of the Creative Commons Attribution license (http://creativecommons.org/licenses/by/4.0/). 